\title{
Emergence of Activity-Dependent, Bidirectional Control of Microtubule-Associated Protein MAP2 Phosphorylation during Postnatal Development
}

\author{
Elizabeth M. Quinlan and Shelley Halpain \\ Department of Neuroscience and the Center for Cell Signaling, University of Virginia, Charlottesville, Virginia 22908
}

\begin{abstract}
Pronounced changes in neuronal morphology occur as synapses mature; however, little is known about how synaptic transmission regulates the developing neuronal cytoskeleton. The postsynaptic, microtubule-associated protein MAP2 is a target of multiple, calcium-dependent signaling pathways activated by synaptic transmission. Here we demonstrate that MAP2 phosphorylation is differentially regulated across development. In ${ }^{32} \mathrm{P}$-labeled hippocampal slices prepared from adult rats, depolarization stimulated a bidirectional change in the phosphorylation of immunoprecipitated MAP2. A transient increase was mediated by metabotropic glutamate receptors (mGluRs) and stimulation of mitogen-activated protein kinases (MAPKs), $\mathrm{Ca}^{2+} /$ calmodulindependent protein kinases (CaMKs), and protein kinase C (PKC). This increase was followed by a persistent dephosphorylation mediated by NMDA receptors and activation of protein phosphatase 2B (PP2B or calcineurin). In contrast, depolarization of neonatal hippocampal slices stimulated exclusively a net increase
\end{abstract}

in MAP2 phosphorylation, which was attenuated by inhibitors of MAPKs, but not CaMKs or PKC. Furthermore, although incubation in NMDA induced a time-dependent decrease in MAP2 phosphorylation in both adults and neonates, this effect was both less robust and less sensitive to calcineurin inhibitors in neonates than in adults. These data indicate that the mechanisms coupling glutamate release to MAP2 dephosphorylation are relatively lacking in the neonatal hippocampus. Highly phosphorylated MAP2 is impaired in its ability to stabilize microtubules and actin filament bundles in vitro. The neonatal propensity toward glutamatestimulated MAP2 phosphorylation may serve to reduce cytoskeletal stability and permit dendritic arborization early in postnatal development. In mature neurons, the bidirectional control of MAP2 phosphorylation may participate in activity-dependent synaptic remodeling.

Key words: glutamate receptor; synaptic plasticity; protein phosphatase; protein kinase; calcineurin; dendrite; microtubules
Modifications in the neuronal cytoskeleton underlie a progression of morphological changes during development that include process outgrowth, neurite arborization, synapse formation, and activity-dependent synapse stabilization/elimination (Goodman and Shatz, 1993). Neuronal morphology is known to be highly responsive to extracellular and intracellular signals; however, it is likely that the nature of cytoskeletal changes and their regulation by signal transduction pathways evolve as a neuron matures.

Microtubules are prominent components of the neuritic cytoskeleton that play an important role in neuronal maturation (Riederer, 1990; Ludin and Matus, 1993). They are composed of tubulin polymers and microtubule-associated proteins (MAPs). Like other structural MAPs, MAP2 regulates microtubule stability. However, in contrast to other prominent neuronal MAPs, such as tau and MAP1b, MAP2 is selectively enriched in neuronal somata and dendrites (Bernhardt and Matus, 1984) and interacts with actin as well as with microtubules in vitro. MAP2 has been implicated in dendrite outgrowth (Caceres et al., 1992; LeClerc et al., 1993; Sharma et al., 1994) and in activity-dependent changes

Received July 16, 1996; revised Sept. 12, 1996; accepted Sept. 18, 1996.

This work was supported by National Institutes of Health (NIH) Grant MH50861 (S.H.). E.M.Q. was supported by NIH Training Grant NS07199. We thank Dr. Richard Vallee for providing MAP2 antibody and Dr. Alan Saltiel for providing PD098059.

Correspondence should be addressed to Shelley Halpain, Department of Cell Biology, The Scripps Research Institute, 10550 North Torrey Pines Road, La Jolla, CA 92037.

Elizabeth Quinlan's present address: Department of Neuroscience, Brown University, Providence, RI 02912.

Copyright $(\odot) 1996$ Society for Neuroscience $\quad 0270-6474 / 96 / 167627-11 \$ 05.00 / 0$ in synaptic connectivity (Aoki and Siekevitz, 1985) and, therefore, is a likely target of signal transduction pathways activated by transmembrane signals during several stages of development.

Multiple isoforms of MAP2 are encoded by a single gene the mRNA of which undergoes differential alternative splicing during development (Kalcheva et al., 1995). All isoforms contain three to four copies of an 18-amino-acid imperfect repeat within the C-terminal microtubule-binding region, a binding site for the RII regulatory subunit of cAMP-dependent protein kinase (PKA) near the $\mathrm{N}$ terminus, and consensus sequences for phosphorylation by multiple Ser/Thr protein kinases (Lewis et al., 1988; Obar et al., 1989; Rubino et al., 1989; Kindler et al., 1990). In vitro, phosphorylation of MAP2 decreases its ability to promote microtubule stability and attenuates its actin-bundling activity (Jameson and Caplow, 1981; Nishida et al., 1981; Murthy and Flavin, 1983; Selden and Pollard, 1983). Two low-molecular-weight $\left(M_{\mathrm{r}} 70\right.$ $\mathrm{kDa}$ ) isoforms (MAP2c and MAP2d) and two high-molecularweight $\left(M_{\mathrm{r}} 280 \mathrm{kDa}\right)$ isoforms (MAP2a and MAP2b) exist. Lowmolecular-weight MAP2s have been detected in glia as well as neurons (Charriere-Bertrand et al., 1991; Doll et al., 1993), but the high-molecular-weight MAP2s are neuron-specific (Matus, 1994). MAP2b is continuously expressed throughout development of the nervous system into adulthood. MAP2a, containing an additional 82-amino-acid insert within the $\mathrm{N}$-terminal region, is detectable in rat brain after postnatal day 10 (P10) (Binder et al., 1984; Riederer and Matus, 1985; Chung et al., 1996). The present study focused on the regulation of high-molecular-weight MAP2, because at least one isoform of this species is present throughout postnatal development. 
Our previous studies revealed that the phosphorylation of MAP2 is regulated in response to glutamate receptor activation (Halpain and Greengard, 1990; Quinlan and Halpain, 1996). The direction of the change in MAP2 phosphorylation is determined by which glutamate receptor subtype and resultant calciumdependent biochemical pathways are engaged. These results support a role for MAP2 in mediating glutamate-dependent morphological plasticity. Here, the regulation of MAP2 phosphorylation was examined at a time when neuronal shape is known to be changing rapidly, that is, during early postnatal development. The data indicate that, although it already possesses the biochemical machinery for coupling glutamate receptor stimulation to an increase in MAP2 phosphorylation, the neonatal hippocampus lacks the full ability to couple glutamate receptor stimulation to a decrease in MAP2 phosphorylation. This observation suggests that neonatal dendritic microtubules are relatively protected from the stabilizing effect of MAP2 dephosphorylation.

\section{MATERIALS AND METHODS}

Preparation and labeling of hippocampal slices. Hippocampi were removed from sexually mature adult female (P42-P45) or neonatal (P6-P23) Sprague Dawley rats after anesthetization via $\mathrm{CO}_{2}$ narcosis in compliance with U.S. Department of Health and Human Services and University of Virginia guidelines. Transverse sections $(450 \mu \mathrm{m}$ thick) were prepared using a Mcllwain tissue chopper and preincubated for $45 \mathrm{~min}$ at $33^{\circ} \mathrm{C}$ in $5 \mathrm{ml}$ of low-calcium, phosphate-free artificial CSF (ACSF) consisting of (in mM): $124 \mathrm{NaCl}, 4 \mathrm{KCl}, 25 \mathrm{Na}_{2} \mathrm{HCO}_{3}, 1.5 \mathrm{MgCl}_{2}, 0.015 \mathrm{CaCl}_{2}$, and 10 glucose, $\mathrm{pH} 7.35 \pm 0.05$, continuously saturated with $95 \% \mathrm{O}_{2} / 5 \% \mathrm{CO}_{2}$ gas. To incorporate label into endogenous ATP pools, slices were incubated for $90 \mathrm{~min}$ in $0.5 \mathrm{ml}$ of ACSF as above, except that $\mathrm{MgCl}_{2}$ was omitted, $\mathrm{CaCl}_{2}$ was increased to $1.5 \mathrm{~mm}$, and $0.25 \mathrm{mCi}$ of $\left[{ }^{32} \mathrm{P}\right]$ orthophosphate was added $(25 \mathrm{mCi} / \mathrm{ml}$; DuPont NEN, Boston, MA). Pharmacological agents were added to the slices at the end of the $90 \mathrm{~min}$ labeling period. Phosphorylation reactions were terminated by aspiration of the ACSF and submersion of slices in liquid nitrogen. 1S,3R-ACPD and NMDA were obtained from Tocris Cookson; chelerythrine and KN-62 from Kamiya Biochemicals; cypermethrin from LC Laboratories; and W-7 from Calbiochem. All other reagents were standard laboratory grade. PD098059 was a gift from Dr. A. Saltiel, Parke-Davis. Monoclonal antibody 2-4 was a gift from Dr. R. Vallee, Worcester Foundation for Experimental Biology.

Quantification of ${ }^{32} \mathrm{P}$ incorporation. Triplicates of identically treated frozen slices were homogenized by sonication in $0.2 \mathrm{ml}$ of boiling $1 \%$ SDS as described previously (Halpain and Greengard, 1990). To assay ${ }^{32} \mathrm{P}$ incorporation into total protein, $7.5 \mu \mathrm{g}$ of hippocampal homogenate was spotted on filter paper (Whatman), rinsed twice for 10 min each with trichloroacetic acid 10\%, rinsed in $95 \%$ ethanol (10 min), and quantified by counting Cerenkov radiation with a Beckman scintillation counter. To determine ${ }^{32} \mathrm{P}$ incorporation into MAP2, hippocampal homogenates were first diluted 1:1 with a buffer consisting of (in mM): $100 \mathrm{NaCl}, 50$ Tris-HCl, pH 7.4, 5 EDTA, $50 \mathrm{NaF}$, and $6 \%$ (v/v) Nonidet P-40. MAP2 was immunoprecipitated from $100 \mu \mathrm{g}$ of each homogenate by a $60 \mathrm{~min}$ incubation at $4^{\circ} \mathrm{C}$ with $5 \mu \mathrm{l}$ of MAP 2 monoclonal antibody 2-4, followed by $30 \mathrm{~min}$ incubation at $4^{\circ} \mathrm{C}$ with $150 \mu \mathrm{l}$ of Pansorbin (Calbiochem). Monoclonal antibody 2-4 recognizes an epitope within the tubulinbinding region of MAP2 (Dingus et al., 1994) and was affinity-purified from mouse ascites using Affigel protein A (Bio-Rad). Immunoprecipitated proteins were separated on $6.5 \%$ SDS-PAGE gels, and ${ }^{32} \mathrm{P}$ incorporation into immunoprecipitated MAP2 was background-corrected and quantified using the volume integration feature of ImageQuant software on a Molecular Dynamics PhosphorImager. Unless otherwise stated, data for experimental groups are expressed as the percentage of MAP2 phosphorylation observed in control slices incubated in parallel in the same experiment. Results from experimental groups were probed for statistical differences compared to controls using one-sample $t$ tests (two-tailed) or one-way ANOVA with correction for multiple comparisons.

Assay of MAP kinase activation. Assay of MAP kinase activation was performed using the PhosphoPlus MAPK Antibody Kit (New England BioLabs), essentially following the manufacturer's instructions. Briefly, hippocampal slices were prepared as above, but with $\mathrm{KCl}$ lowered to 2.5 $\mathrm{mm}$ and $1.5 \mathrm{mM} \mathrm{KH}_{2} \mathrm{PO}_{4}$ substituted for $\left[{ }^{32} \mathrm{P}\right]$ orthophosphate. Slices were incubated in the absence or presence of various compounds and reactions stopped by immersion in liquid nitrogen. Frozen slices were solubilized by sonication into $120 \mu \mathrm{l}$ of boiling 1\% SDS; triplicate samples were combined and equalized for protein content. Forty micrograms of homogenate were separated by SDS-PAGE using $10 \%$ minigels and transferred to nitrocellulose. Replicate blots were prepared of each sample plus lanes containing aliquots of either nonphosphorylated ("inactive") MAPK (recombinant Erk2 protein) or "active" MAPK fully phosphorylated by the activating kinase MEK (both standards provided with the kit). Blots were probed using either an antibody specific to MAP kinases but independent of phosphorylation state or with a phosphoepitope-specific antibody that binds MAPKs only when phosphorylated on Tyr within the activation domain (e.g., $\mathrm{Tyr}^{204}$ in human $\left.\mathrm{p} 44 \mathrm{MAPK}\right)$. Immunoreactivity was detected using the kit's chemiluminescent detection system and Kodak XR5 film. Digital images from densitometric scans of the autoradiographs were transferred to Adobe Photoshop for cropping and to Microsoft PowerPoint for assembly and labeling of relevant portions of the images.

Other methods. Homogenate protein concentrations were measured by the bicinchoninic acid method (Pierce) using bovine serum albumin as a standard. MAP2 concentration was determined by quantitative immunoblot analysis in which hippocampal slices were prepared as above, but with $\mathrm{KCl}$ lowered to $2.5 \mathrm{~mm}$ and $1.5 \mathrm{~mm} \mathrm{KH}_{2} \mathrm{PO}_{4}$ substituted for $\left[{ }^{32} \mathrm{P}\right]$ orthophosphate. Aliquots of homogenates from combined triplicates containing $100 \mu \mathrm{g}$ of protein were separated on 6.5\% SDS-PAGE gels and then transferred to nitrocellulose as described previously (Halpain and Greengard, 1990). Nitrocellulose sheets were incubated at room temperature in anti-MAP2 monoclonal antibody 2-4 (1:5000 for $2 \mathrm{hr})$, followed by rabbit anti-mouse $\operatorname{IgG}(1: 2000$ for $2 \mathrm{hr})$ and ${ }^{125}$ I-labeled protein A (30 mCi/mg, 1:2000 for $2 \mathrm{hr}$; Amersham) in Tris-buffered saline, $\mathrm{pH} 7.35$, containing $4 \%$ nonfat dry milk and $0.1 \%$ Triton X-100. MAP2 levels were assayed by quantification of $\left.{ }^{125} \mathrm{I}\right]$ protein A-labeled MAP2 using the volume integration function of a Molecular Dynamics PhosphorImager.

\section{RESULTS}

\section{Developmental regulation of hippocampal protein phosphorylation}

Before exploring developmental differences in the regulation of MAP2 phosphorylation, it was first necessary to verify that the slice preparation and assay methods developed to examine protein phosphorylation in the adult hippocampus were adaptable to studies using neonatal hippocampus. Phosphorylation efficiency was assayed by quantifying ${ }^{32} \mathrm{P}$ incorporation into trichloroacetic acid-precipitable protein in slices prepared in parallel from adult, $\mathrm{P} 16$, and $\mathrm{P} 7$ rats. ${ }^{32} \mathrm{P}$ incorporation reached a plateau within 90 min, demonstrating that slices prepared from all ages retained metabolic activity in vitro. However, the maximal amount of ${ }^{32} \mathrm{P}$ incorporation was significantly higher in tissue prepared from $\mathrm{P} 7$ and $\mathrm{P} 16$ slices as compared to adults (Fig. $1 A$ ). This may reflect a higher rate of phosphate turnover or general metabolic activity in neonatal versus adult tissue.

The ability to study the regulation of MAP2 phosphorylation over development was examined by quantifying ${ }^{32} \mathrm{P}$ incorporation into immunoprecipitated high-molecular-weight MAP2 for adult, $\mathrm{P} 16$, and P7 hippocampal slices. Although ${ }^{32} \mathrm{P}$ incorporation into MAP2 reached a plateau more rapidly in $\mathrm{P} 7$ than adult slices (75 min for P7 vs 90 min for adults), the maximum amount of ${ }^{32} \mathrm{P}$ incorporation per $\mu \mathrm{g}$ of MAP2 protein was similar for the three age groups (Fig. $1 B$ ). This demonstrates that the relative fragility of hippocampal tissue from neonatal brain does not compromise metabolic integrity for assays of protein phosphorylation and that hippocampal slices can be used to study the regulation of MAP2 phosphorylation over development.

\section{Developmental expression of bidirectional changes in hippocampal MAP2 phosphorylation}

A bidirectional change in MAP2 phosphorylation can be stimulated in adult hippocampal slices by blocking the uptake of endo- 

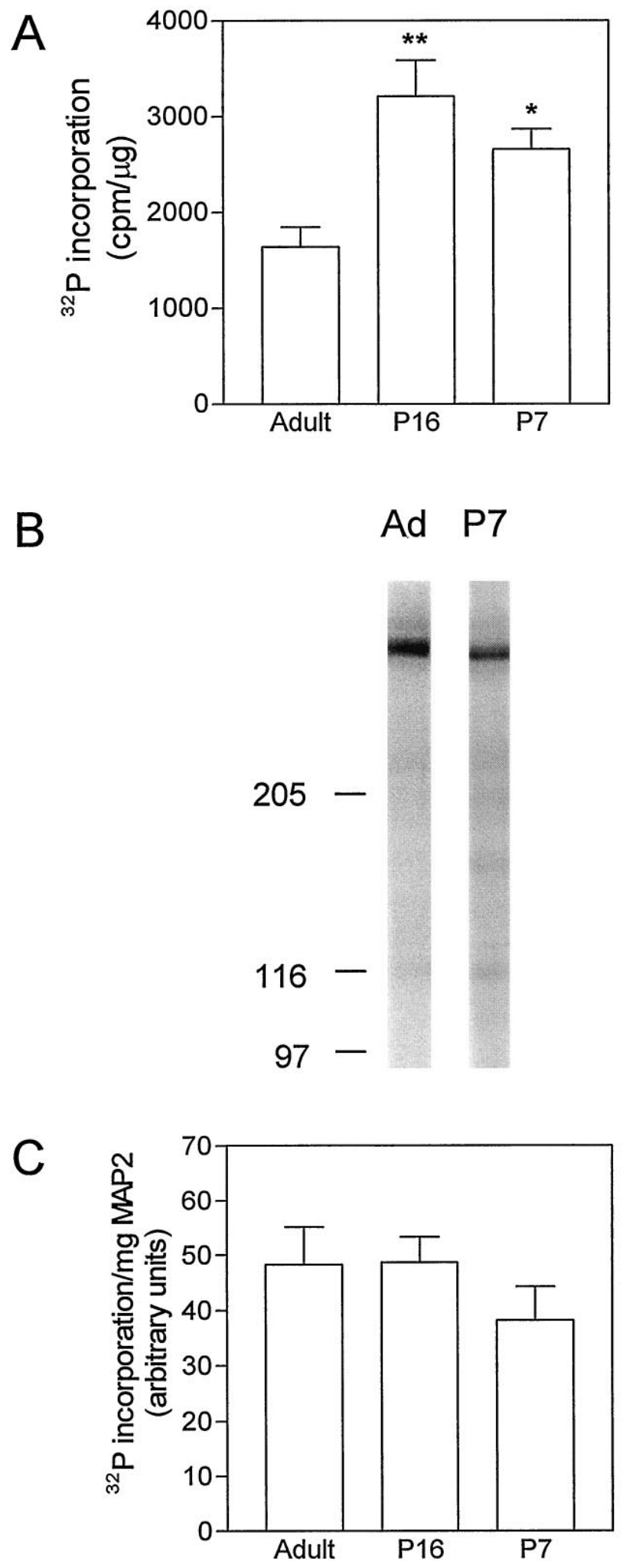

Figure 1. Phosphate incorporation into total hippocampal protein and immunoprecipitated MAP2 over development. $A$, Slices prepared from adult, P16, and P7 rat hippocampus were metabolically labeled with $\left[{ }^{32} \mathrm{P}\right]$ orthophosphate for $90 \mathrm{~min}$ as described in Materials and Methods. The amount of ${ }^{32} \mathrm{P}$ incorporation into trichloroacetic acid-precipitable protein was assayed in equal aliquots of homogenate solubilized in $1 \%$ SDS. ${ }^{32} \mathrm{P}$ incorporation per $\mathrm{mg}$ protein was significantly higher in $\mathrm{P} 16$ and P7 hippocampal slices compared to adult $\left({ }^{*} p \leq 0.05,{ }^{* *} p \leq 0.01\right.$; one-way ANOVA with Bonferroni post hoc comparison). Data are expressed as ${ }^{32} \mathrm{P}$ genously released glutamate with dihydrokainate (DHK) (Quinlan and Halpain, 1996), suggesting that synaptic transmission at glutamatergic synapses may normally regulate MAP2 phosphorylation in vivo. To test this hypothesis, incubation in $40 \mathrm{~mm} \mathrm{KCl}$ was used in an effort to elicit synchronous depolarization throughout the hippocampal slice. Depolarization of slices from adult rats induced a bidirectional change in MAP2 phosphorylation, which was similar to that previously observed in the presence of DHK. A transient increase in MAP2 phosphorylation peaked within $30 \mathrm{sec}$ (to $179 \pm 8 \%$ of control); this was followed by a persistent net decrease in MAP2 phosphorylation, lasting at least $30 \mathrm{~min}$ (Fig. $2 A$ ). A similar bidirectional change in MAP2 phosphorylation was observed in slices prepared from P21-P23 rats (Fig. 2B). In contrast, depolarization of hippocampal slices from younger animals induced primarily a net increase in MAP2 phosphorylation. In P17-P18 slices, MAP2 phosphorylation increased to $217 \pm$ $28 \%$ of control after 1 min of depolarization, remained elevated relative to control for $\geq 10 \mathrm{~min}$, and decreased slowly to $71.1 \pm$ $14.5 \%$ of control over 30 min (Fig. 2C). Depolarization of P7-P8 slices induced a net increase in MAP2 phosphorylation (Fig. 2D). A robust increase in MAP2 phosphorylation (to $225 \pm 13 \%$ of control) peaked rapidly, within $15 \mathrm{sec}$ of the addition of $40 \mathrm{~mm}$ $\mathrm{KCl}$. The large increase was transient, with MAP2 phosphorylation reduced to $152 \pm 12 \%$ of control by $30 \mathrm{sec}$ and to $133 \pm 17 \%$ of control within $10 \mathrm{~min}$. However, MAP2 phosphorylation remained elevated relative to baseline for at least $30 \mathrm{~min}$.

\section{Stimulation of MAP2 phosphorylation in adult versus neonatal hippocampus: role of protein kinases}

Differences in depolarization-induced changes in MAP2 phosphorylation across development may reflect many factors, including differences in neuronal excitability, probability of transmitter release, expression of neurotransmitter receptors subtypes, or efficacy of signal transduction pathways that target MAP2 in neonates versus adults. To begin to distinguish among these possibilities, the role of specific glutamate receptor subtypes and components of phosphorylation pathways were explored.

MAP2 is efficiently phosphorylated by several classes of Ser/Thr protein kinases in vitro, including cAMP-dependent protein kinase (PKA) (Sloboda et al., 1975; Vallee, 1980; Walaas and Nairn, 1989), proline-directed kinases, such as mitogen-activated protein kinase (MAPK) (Ray and Sturgill, 1987; Berling et al., 1994; Sanchez et al., 1995), protein kinase C (PKC) (Akiyama et al., 1986; Tsuyama et al., 1986; Walaas and Nairn, 1989), and $\mathrm{Ca}^{2+}$ / calmodulin-dependent protein kinase type II (CaMKII) (Schulman, 1984; Goldenring et al., 1985; Yamamoto et al., 1985; Walaas and Nairn, 1989). To identify protein kinases that target MAP2 in situ, and to test for developmental differences in signaling pathways, the effect of inhibition of three classes of Ser/Thr

incorporation in $\mathrm{cpm} / \mu \mathrm{g}$ homogenate and represent the mean \pm SEM of four experiments, each performed in triplicate. $B$, Metabolically labeled slices prepared from adult, P16, and P7 rat hippocampus were assayed for ${ }^{32} \mathrm{P}$ incorporation into immunoprecipitated high-molecular-weight MAP2 and expressed per mg of MAP2 protein. ${ }^{32} \mathrm{P}$ incorporation was not significantly different for the three age groups examined (one-way ANOVA) ${ }^{32} \mathrm{P}$ incorporation was determined by PhosphorImager analysis, MAP2 concentration was determined by quantitative immunoblot. Data are expressed in arbitrary units, calculated as the counts of ${ }^{32} \mathrm{P}$ in immunoprecipitated MAP2 divided by the counts of $\left[{ }^{125}\right.$ I]protein A-labeled MAP2 detected by quantitative immunoblot analysis $(n=4$ experiments, each performed in triplicate). 

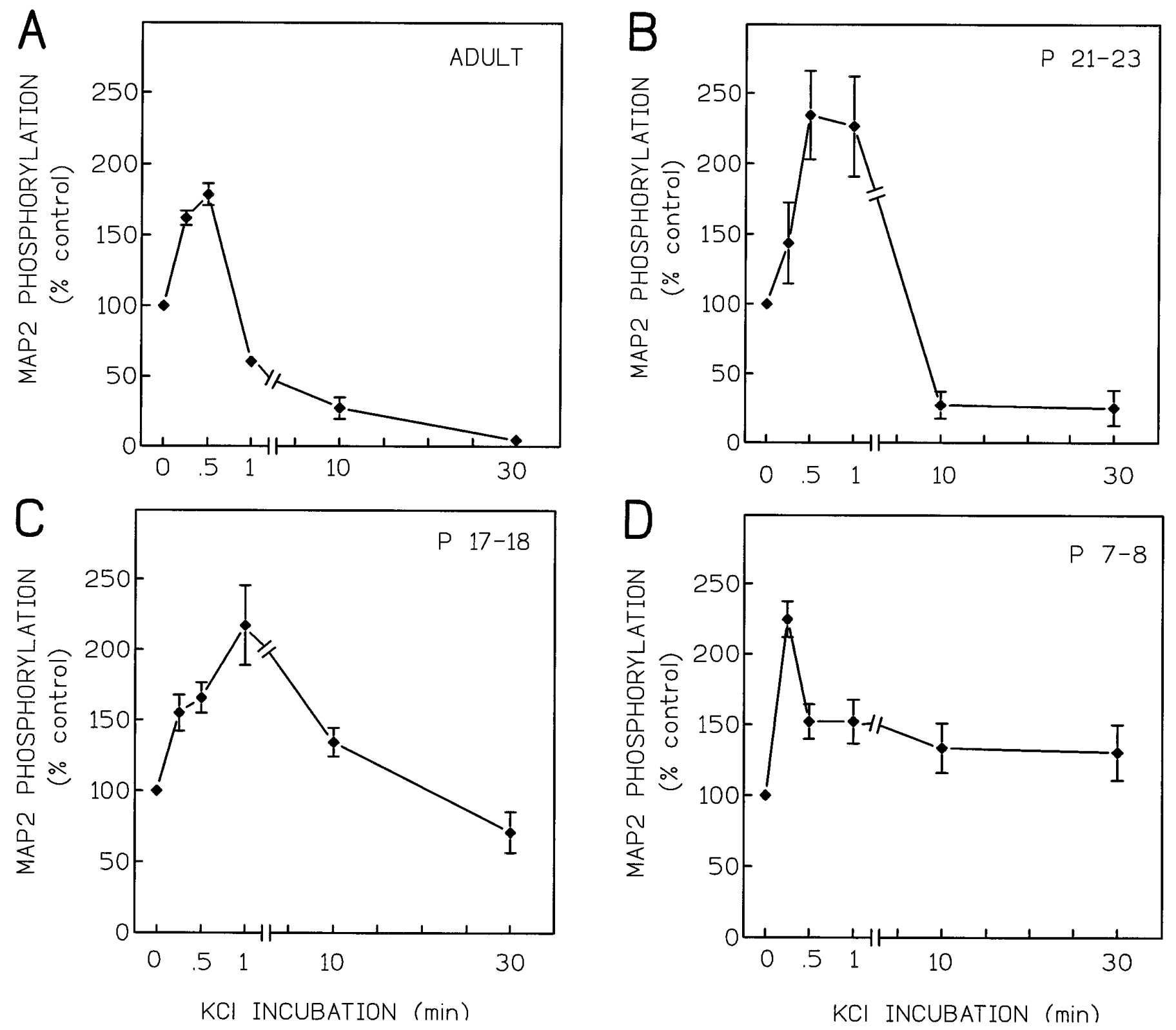

Figure 2. Developmental expression of depolarization-induced changes in MAP2 phosphorylation. ${ }^{32} \mathrm{P}$-labeled hippocampal slices were incubated in ACSF plus $40 \mathrm{~mm} \mathrm{KCl}$ for the times indicated before immunoprecipitation of MAP2. Data are expressed as the percentage of MAP2 phosphorylation observed in control slices incubated in ACSF alone. Slices were prepared from the hippocampus of rats of the indicated ages: $A$, adult (P42-P45); $B$, P21-P23; C, P17-P18; D, P7-P8. Each data point represents the mean \pm SEM of three to five complete time courses performed in triplicate.

protein kinases on basal MAP2 phosphorylation was examined in adult and $\mathrm{P} 7$ hippocampus.

The compound PD098059 recently was reported to selectively inhibit MAPK activity by inhibiting the MAPK-activating enzyme MEK1 both in vitro and in intact cells (Alessi et al., 1995). To determine whether PD098059 can inhibit MAPK activation in hippocampal tissue, adult slices were incubated in the absence or presence of $150 \mu \mathrm{M}$ PD098059 and assayed for MAPK activation by immunoblot analysis using a phosphoepitope-specific antibody that detects the active form of MAPK. This concentration of PD098059 inhibited nearly all detectable MAPK activation in control slices as well as in slices stimulated for $30 \mathrm{sec}$ with high $\mathrm{K}^{+}$ (Fig. 3). Subsequent studies used $150 \mu \mathrm{M}$ PD098059 to examine the effect of MAPK blockade on MAP2 phosphorylation. KN62 is a potent and selective inhibitor of $\mathrm{Ca}^{2+} /$ calmodulin-dependent protein kinases (CaMKs), including CaMKII; chelerythrine (CHE) is a potent and selective inhibitor of PKC. Both compounds have been used extensively in neurobiological studies, including hippocampal slices (Quinlan and Halpain, 1996). Experiments were performed using concentrations of the inhibitors determined to be maximally effective in the slice preparation.

In hippocampal slices prepared from adult rats, each inhibitory compound blocked a significant amount of basal ${ }^{32} \mathrm{P}$ incorporation into MAP2, indicating that all three classes of protein kinase contribute to the basal phosphorylation of MAP2 in situ (Fig. 4). MAP2 phosphorylation was reduced to $19.8 \pm 8.5 \%$ of control in the presence of PD098059. The CaMK and PKC inhibitors were less effective, decreasing MAP2 phosphorylation to $48 \pm 8.3$ and 


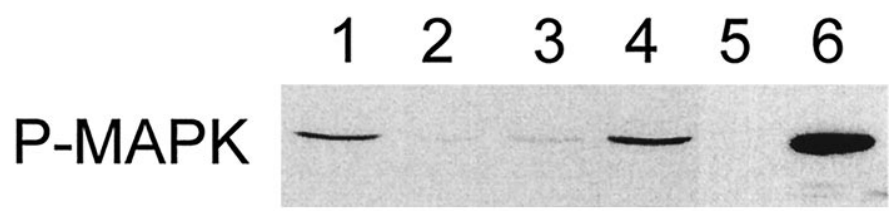

MAPK

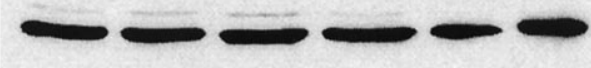

Figure 3. Effect of the MEK inhibitor PD098059 on MAPK activation. Hippocampal slices were incubated in the absence or presence of $150 \mu \mathrm{M}$ PD098059 and $40 \mathrm{~mm} \mathrm{KCl}$. Forty micrograms of homogenate from each stimulation condition were loaded onto replicate gels, transferred to nitrocellulose, and immunoblotted using antibodies that recognized either the active, phosphorylated fraction of MAPK (top) or the total fraction of MAPK (bottom). Lane 1, Control; lane 2, PD098059 (30 min); lane 3, PD098059 (30 min) plus $\mathrm{K}^{+}(30 \mathrm{sec})$; lane $4, \mathrm{~K}^{+}$(30 sec); lane 5, $8 \mathrm{ng}$ of unphosphorylated MAPK Erk2 protein; lane $6,8 \mathrm{ng}$ of phosphorylated MAPK Erk2 protein.

$81 \pm 14 \%$ of control, respectively. These results suggests that of the three classes of protein kinase examined, MAPK activity contributes most strongly to the basal state of MAP2 phosphorylation in the adult hippocampus. In contrast, MAPK activity appears to contribute little to the basal MAP2 phosphorylation in P7 hippocampus, because incubation in PD098059 did not significantly alter ${ }^{32} \mathrm{P}$ incorporation into MAP2 (99 $\pm 27 \%$ of control). KN62 and CHE were partially effective at inhibiting MAP2 phosphorylation, demonstrating that $\mathrm{CaMK}$ and $\mathrm{PKC}$ contribute to basal MAP2 phosphorylation in P7 slices.

Potassium-induced depolarization increases MAP2 phosphorylation in both adult and neonatal slices, but with distinct temporal dynamics (Fig. 2). Developmental differences in protein kinase pathways that target MAP2 might account for these differences in the MAP2 phosphorylation time course. To test this hypothesis, the effects of three protein kinase inhibitors on $\mathrm{K}^{+}$-induced MAP2 phosphorylation were examined (Fig. 5). In the adult

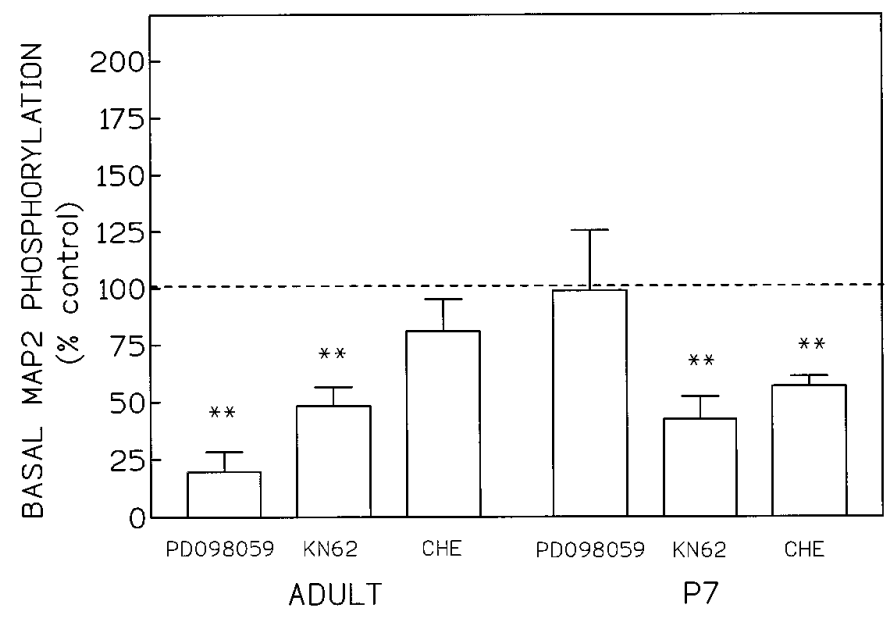

Figure 4. Effects of protein kinase inhibitors on basal MAP2 phosphorylation in adult and P7 hippocampal slices. ${ }^{32} \mathrm{P}$-labeled hippocampal slices were incubated for $30 \mathrm{~min}$ in the absence or presence of PD098059 (150 $\mu \mathrm{M})$, KN62 $(15 \mu \mathrm{M})$, or CHE $(15 \mu \mathrm{M})$ before MAP2 immunoprecipitation. Data are expressed as the percentage of MAP2 phosphorylation observed in control slices incubated in the absence of protein kinase inhibitors (dashed line). Each data point represents the mean \pm SEM of four experiments, each performed in triplicate: ${ }^{* *} p \leq 0.01$, one-sample $t$ test.

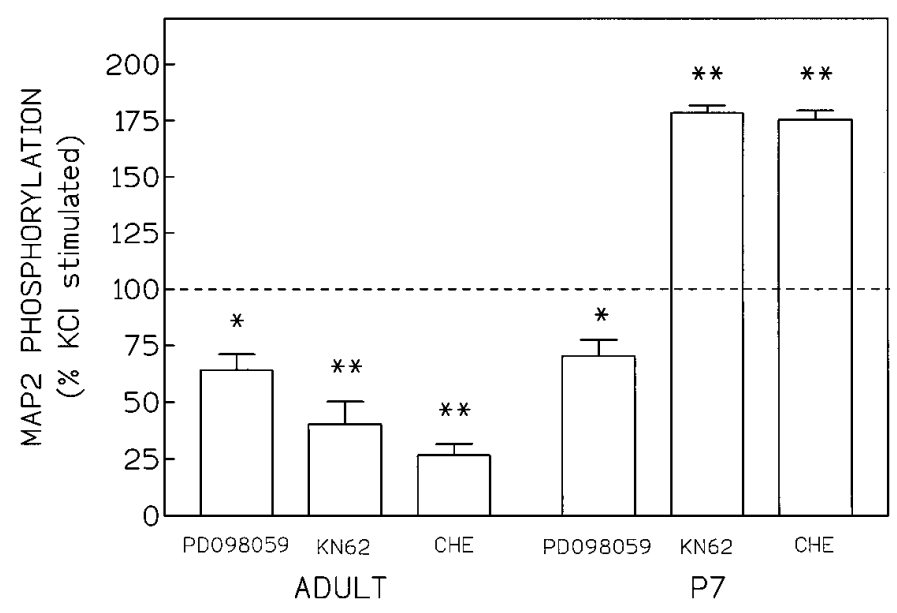

Figure 5. Effects of protein kinase inhibitors on depolarization-induced MAP2 phosphorylation in adult and P7 hippocampal slices. ${ }^{32} \mathrm{P}$-labeled hippocampal slices were incubated for $30 \mathrm{~min}$ in the absence or presence of protein kinase inhibitors followed by $30 \mathrm{sec}$ incubation with $40 \mathrm{mM} \mathrm{KCl}$ before MAP2 immunoprecipitation. Incubation in inhibitory compounds alone affects basal MAP2 phosphorylation (Fig. 4); therefore, each data point for each age group is expressed as counts in protein kinase inhibitor $+30 \mathrm{sec} \mathrm{KCl}$ divided by counts in protein kinase inhibitor alone and normalized to MAP2 phosphorylation observed after $30 \mathrm{sec}$ of $\mathrm{KCl}$ (dashed line). In slices prepared from adult hippocampus, PD098059, KN62, and CHE each significantly inhibited KCl-induced MAP2 phosphorylation. In slices from P7 hippocampus, PD098059 inhibited, but KN62 and CHE enhanced, the KCl-induced MAP2 phosphorylation. Each data point represents the mean \pm SEM of four experiments, each performed in triplicate: ${ }^{*} p \leq 0.05,{ }^{*} p \leq 0.01$; one-sample $t$ test.

hippocampus PD098059, KN62 and CHE each attenuated the increase in MAP2 phosphorylation induced by a $30 \mathrm{sec}$ incubation in $40 \mathrm{~mm} \mathrm{KCl}$ (to $64.0 \pm 7.1,40.1 \pm 10$, and $26.6 \pm 4.8 \%$, respectively, of the MAP2 phosphorylation observed in $\mathrm{K}^{+}$ alone). In contrast, in P7 hippocampus, only the MAPK inhibitor PD098059 attenuated $\mathrm{K}^{+}$-stimulated MAP2 phosphorylation (to $70.1 \pm 7.3 \%$ of $\mathrm{K}^{+}$alone). Paradoxically, inhibition of CaMK and PKC substantially augmented the $\mathrm{K}^{+}$-induced increase in MAP2 phosphorylation (to $178.3 \pm 3.4$ and $175.4 \pm 4.1 \%$, respectively, of the $\mathrm{K}^{+}$alone condition). This result was unexpected, but highly reproducible, and suggests that the neonatal brain possesses complex mechanisms for cross-talk among phosphorylation pathways targeting MAP2.

\section{Stimulation of MAP2 phosphorylation in adult versus neonatal hippocampus: role of metabotropic glutamate receptors}

In adult hippocampal slices, activation of metabotropic glutamate receptors (mGluRs) with the agonist $1 \mathrm{~S}, 3 \mathrm{R}-\mathrm{ACPD}$ stimulated the phosphorylation of MAP2 (Quinlan and Halpain, 1996). Spontaneously released glutamate induces a comparable effect in the presence of the NMDA receptor blocker MK-801 (Quinlan and Halpain, 1996). In P7 hippocampal slices, 1S,3R-ACPD (200 $\mu \mathrm{M})$ induced a similar time-dependent increase in MAP2 phosphorylation (Fig. 6), as did incubation in MK-801 (data not shown). This suggests that in both mature and immature neurons, mGluRs are strongly linked to signaling pathway(s) that stimulate a net increase in MAP2 phosphorylation.

In contrast to the transient increase in MAP2 phosphorylation observed after brief depolarization, the increased phosphorylation observed in hippocampal slices after ACPD application is slow and sustained. This suggests that endogenous glutamate released 


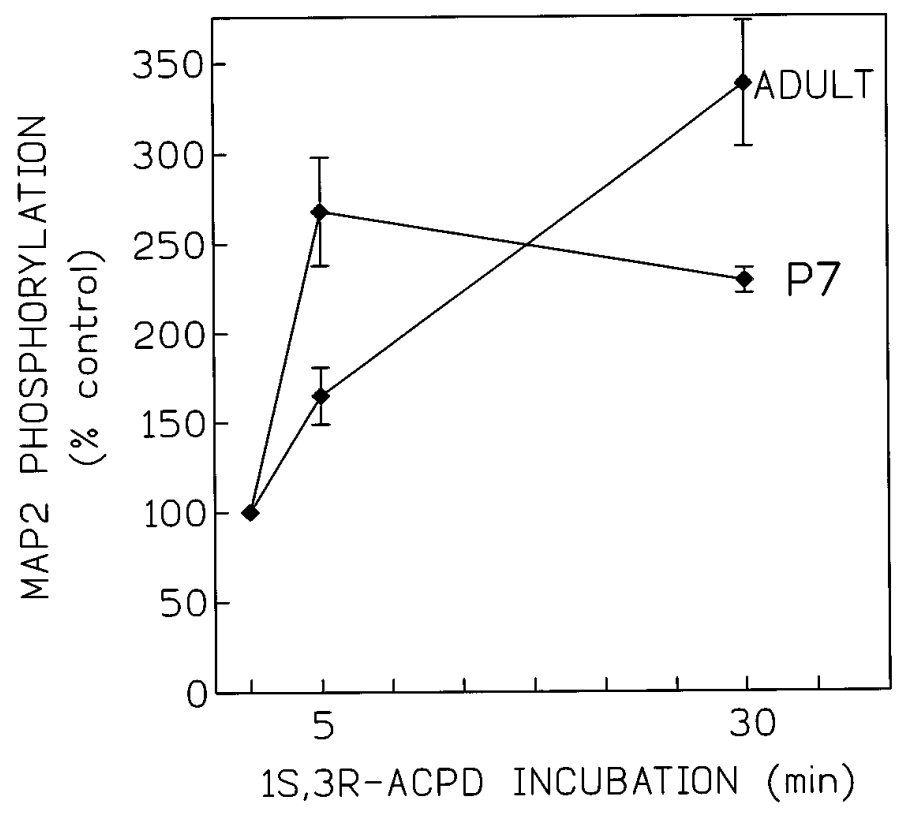

Figure 6. Time course of mGluR-dependent increases in MAP2 phosphorylation in $\mathrm{P} 7$ and adult hippocampus. ${ }^{32} \mathrm{P}$-labeled hippocampal slices prepared from P7 or adult hippocampus were incubated for 5 or $30 \mathrm{~min}$ in the presence of the metabotropic glutamate receptor agonist 1S,3RACPD $(200 \mu \mathrm{M})$ before MAP2 immunoprecipitation. Data are expressed as a percentage of MAP2 phosphorylation observed in control slices incubated in the absence of 1S,3R-ACPD. ACPD application produced a similar time-dependent increase in MAP2 phosphorylation in adult and P7 hippocampal slices. Data for adult samples are reproduced from Quinlan and Halpain (1996). Each data point represents the mean \pm SEM of three to four experiments, each performed in triplicate.

by depolarization activates both NMDA and mGluR receptors. However, it is also possible that depolarization and mGluRs might activate distinct protein kinase pathways that target MAP2. Indeed, experiments using cultured cortical neurons demonstrated that glutamate stimulates CaMKII and MAPK activity with distinct temporal dynamics (Murphy et al., 1994). Therefore, the contribution of MAPK, CaMKs, and PKC to the ACPDstimulated increase in MAP2 phosphorylation was determined and compared to that observed for $\mathrm{K}^{+}$-stimulated MAP2 phosphorylation. Overall, the protein kinase inhibitors had very similar effects on $\mathrm{K}^{+}$- and ACPD-stimulated MAP2 phosphorylation (Fig. 7). In the adult, PD098059, KN62, and CHE each partially attenuated the increase in MAP2 phosphorylation stimulated by ACPD (to $60.9 \pm 4.2,34.9 \pm 6.8$, and $52.2 \pm 7.8 \%$, respectively, of MAP2 phosphorylation in ACPD alone). In P7 slices, however, only the MAPK inhibitor PD098059 attenuated ACPD-stimulated MAP2 phosphorylation, whereas both KN62 and CHE augmented the stimulatory effects of ACPD. This paradoxical effect of KN62 and $\mathrm{CHE}$ was similar to the effect observed on $\mathrm{K}^{+}$stimulated MAP2 phosphorylation in P7 slices (compare Figs. 5 and 7), except that $\mathrm{CHE}$ had a stronger synergistic effect on $\mathrm{K}^{+}$-stimulated than ACPD-stimulated MAP2 phosphorylation.

Together these results suggest that brief $\mathrm{K}^{+}$-induced depolarization and ACPD stimulate similar mGluR-dependent phosphorylation pathways that target MAP2. However, the coupling of mGluRs to effector mechanisms upstream from MAP2 differ greatly in adults and neonates. MAPK activity contributes partially to mGluR-stimulated MAP2 phosphorylation in both adults and neonates, but in adults there are additional contributions from CaM kinases and PKC. In contrast, in P7 slices blockade of

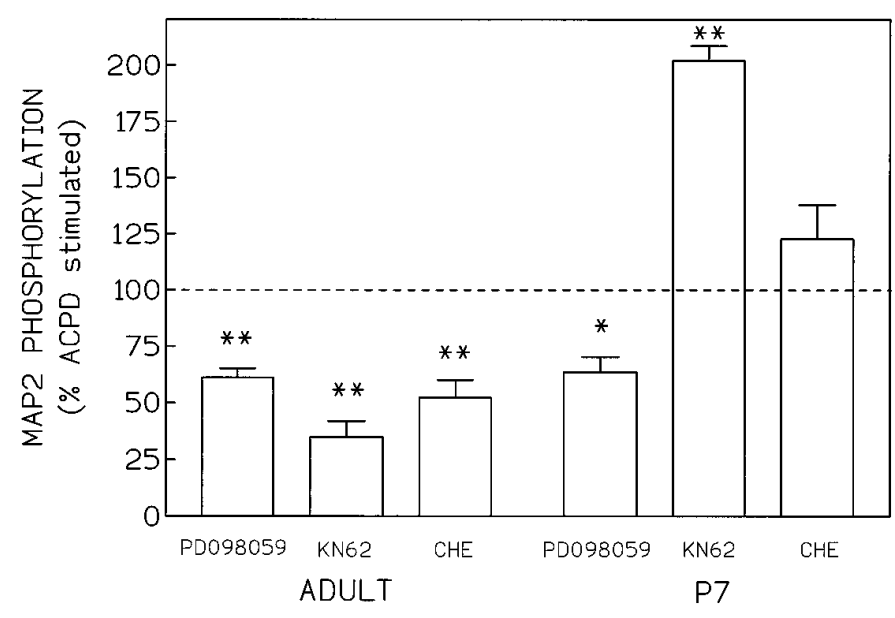

Figure 7. Effects of protein kinase inhibitors on metabotropic glutamate receptor-dependent MAP2 phosphorylation in adult and P7 hippocampal slices. ${ }^{32} \mathrm{P}$-labeled hippocampal slices were incubated for $30 \mathrm{~min}$ in the absence or presence of protein kinase inhibitors followed by $5 \mathrm{~min}$ of 1S,3R-ACPD before MAP2 immunoprecipitation. Incubation in inhibitory compounds alone affects basal MAP2 phosphorylation (Fig. 4); therefore, each data point for each age group is expressed as counts in protein kinase inhibitor +5 min ACPD divided by counts in protein kinase inhibitor alone and normalized to MAP2 phosphorylation observed after 5 min of ACPD (dashed line). In slices prepared from adult hippocampus, PD098059, KN62, and CHE each significantly inhibited ACPD-induced MAP2 phosphorylation. In slices from P7 hippocampus, PD098059 inhibited, but KN62 and CHE enhanced, the ACPD-induced MAP2 phosphorylation. Each data point represent the mean \pm SEM of four experiments, each performed in triplicate: ${ }^{*} p \leq 0.05,{ }^{* *} p \leq 0.01$; one-sample $t$ test.

CaMK and PKC significantly enhanced the effect of mGluR activation. Because the MAPK inhibitor blocked only $35-40 \%$ of mGluR-stimulated MAP2 phosphorylation in P7 slices, it is likely that one or more additional protein kinases contribute to mGluRstimulated MAP2 phosphorylation in immature neurons.

\section{Stimulation of MAP2 dephosphorylation in adult versus neonatal hippocampus: role of NMDA receptors and calcineurin}

In adult hippocampal slices, a substantial decrease in MAP2 phosphorylation was observed within 1 min of $\mathrm{K}^{+}$-induced depolarization (Fig. 2A). Incubation in NMDA induces a similar dephosphorylation of MAP2 (Quinlan and Halpain, 1996). In contrast, depolarization of P7 hippocampal slices resulted only in a net increase in MAP2 phosphorylation (Fig. 2D). This lack of $\mathrm{K}^{+}$-induced dephosphorylation in P7 slices may indicate that the pathway coupling NMDA receptor activation to MAP2 dephosphorylation is weaker during early postnatal development. To test this hypothesis, MAP2 phosphorylation was examined in adult and neonatal hippocampus after NMDA receptor activation. In slices prepared from adult hippocampus, NMDA stimulated a time-dependent decrease in MAP2 phosphorylation, which reached $20.3 \pm 7.3 \%$ of control within $5 \mathrm{~min}$ and decreased further to $3.7 \pm 1.5 \%$ of control after $30 \mathrm{~min}$ (Fig. 8). In slices prepared from P7 hippocampus, NMDA also induced a decrease in MAP2 phosphorylation; however, this decrease was significantly less robust than in adults. After a 5 min incubation in the presence of NMDA, MAP2 phosphorylation in P7 slices was reduced to $55 \pm 5 \%$ of control. In contrast to the further decrease observed in adult slices, MAP2 phosphorylation in P7 slices remained at $44 \pm 3 \%$ of control for up to $30 \mathrm{~min}$ in the presence of 


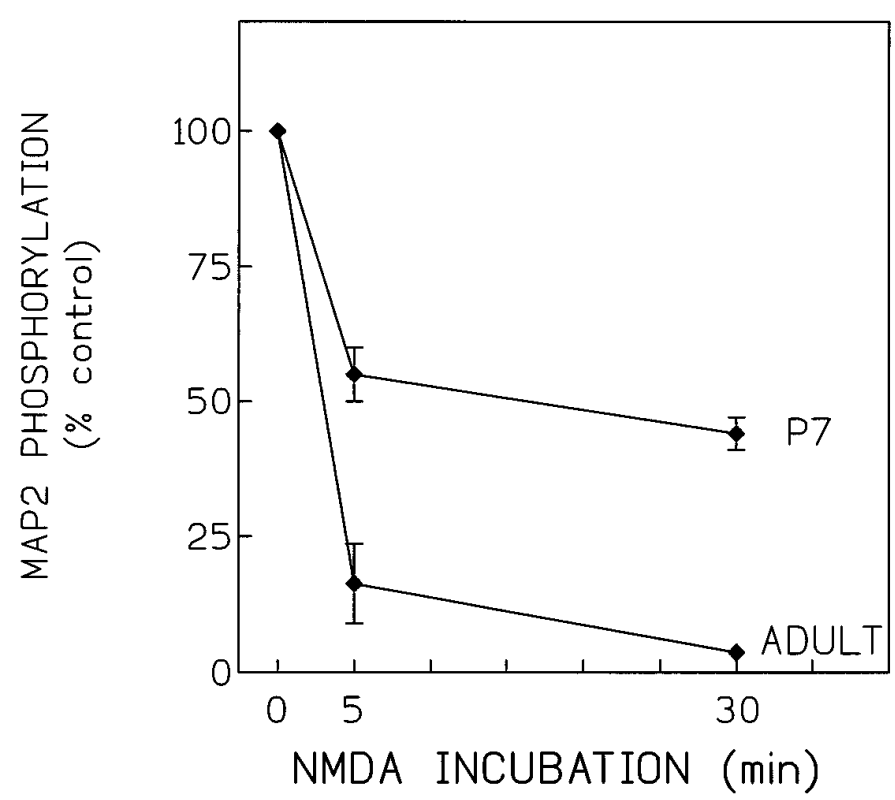

Figure 8. Time course of NMDA receptor-dependent decreases in MAP2 phosphorylation in adult and P7 hippocampus. ${ }^{32} \mathrm{P}$-labeled hippocampal slices were incubated for 5 or $30 \mathrm{~min}$ in the absence or presence of NMDA $(100 \mu \mathrm{M})$ before MAP2 immunoprecipitation. Data are expressed as a percentage of MAP2 phosphorylation observed in control slices incubated in the absence of NMDA. NMDA application produced a time-dependent decrease in MAP2 phosphorylation that was more robust in the adult versus neonatal hippocampus. The error bar is smaller than the symbol for the 30 min time point in the adult hippocampus. Each data point represents the mean \pm SEM of five to six experiments, each performed in triplicate.

NMDA (Fig. 8). These results suggest that MAP2 dephosphorylation is more weakly coupled to NMDA receptor stimulation during the first postnatal week.

High-molecular-weight MAP2 can be efficiently dephosphorylated in vitro by several classes of Ser/Thr protein phosphatases including protein phosphatase 1 (PP1) and/or protein phosphatase 2A (PP2A) (Goto et al., 1985) and the $\mathrm{Ca}^{2+}$ calmodulin-dependent protein phosphatase 2B (PP2B or calcineurin) (Yamamoto et al., 1988). Previous studies with adult hippocampal slices indicated that the NMDA-induced dephosphorylation of MAP2 was largely mediated by calcineurin, because inhibitors of PP2B, but not PP1 or PP2A, attenuated this effect (Quinlan and Halpain, 1996). To examine whether calcineurin activity contributed to the modest NMDAinduced dephosphorylation of MAP2 in neonatal hippocampus, the specific, lipid-permeable calcineurin inhibitor cypermethrin (Enan and Matsumura, 1993) was used. Cypermethrin induced a small but statistically insignificant increase in basal MAP2 phosphorylation in adult and P7 hippocampal slices, but it significantly attenuated the NMDA-induced decrease in MAP2 phosphorylation in both ages (Table 1). However, in P7 slices cypermethrin inhibited a smaller percentage of the NMDAinduced dephosphorylation of MAP2 as compared to adults. These data suggest that the NMDA-induced dephosphorylation of MAP2 is mediated, in part, by calcineurin in both the adult and P7 hippocampus; however, the NMDA-induced dephosphorylation of MAP2 is both less robust and less sensitive to calcineurin inhibition in neonates than in adults.

\begin{tabular}{|c|c|c|}
\hline & Adult & P7 \\
\hline \multicolumn{3}{|l|}{$300 \mu \mathrm{M}$ CYP } \\
\hline (\% control) & $112.1 \pm 8.4$ & $132.1 \pm 16.2$ \\
\hline \multicolumn{3}{|l|}{$100 \mu \mathrm{M}$ NMDA } \\
\hline (\% control) & $20.3 \pm 7.3^{*}$ & $55.0 \pm 5.0^{* \#}$ \\
\hline \multicolumn{3}{|l|}{$\mathrm{CYP}+\mathrm{NMDA}$} \\
\hline (\% of CYP) & $47.2 \pm 5.5^{*}$ & $74.9 \pm 9.8^{\#}$ \\
\hline$\%$ Inhibition & $57.8 \pm 5.9^{*}$ & $26.6 \pm 7.5^{* \#}$ \\
\hline
\end{tabular}

${ }^{32} \mathrm{P}$-labeled hippocampal slices were incubated in the absence or presence of the calcineurin inhibitor cypermethrin (CYP; $30 \mathrm{~min}, 300 \mu \mathrm{M})$, NMDA $(5 \mathrm{~min}, 100 \mu \mathrm{M})$, or both, before MAP2 immunoprecipitation. The effects of cypermethrin and NMDA are expressed as the percentage of MAP2 phosphorylation observed in control slices. The effect of cypermethrin on NMDA-induced dephosphorylation is expressed as the percentage of MAP2 phosphorylation observed in the presence of cypermethrin alone (\% of CYP) and as the percentage of the NMDA-induced MAP2 dephosphorylation inhibited by cypermethrin (\% inhibition). Each data point represents mean \pm SEM of three to four experiments, each performed in triplicate; ${ }^{*} p$ $<0.05$ versus control; ${ }^{\#} p<0.05$ versus adult; one-sample $t$ test.

\section{Model for the regulation of MAP2 phosphorylation in adult versus $\mathrm{P7}$ hippocampus}

These data support the following model for the bidirectional control of MAP2 phosphorylation at glutamatergic synapses in adult versus developing neurons. In the adult hippocampus, activation of mGluRs and the resultant activation of MAPK, CaMKs, and PKC induces a net increase in MAP2 phosphorylation (Fig. $9 A$ ). Increased MAP2 phosphorylation is predicted to decrease the interactions of MAP2 with microtubules and filamentous actin, thereby promoting a decrease in cytoskeletal stability. However, activation of NMDA receptors, and the resultant stimulation of the $\mathrm{Ca}^{2+} /$ calmodulin-dependent protein phosphatase calcineurin, results in a net decrease in MAP2 phosphorylation. Dephosphorylation of MAP2 is predicted to increase the interactions of MAP2 with microtubules and F-actin, thereby promoting cytoskeletal stabilization. In the adult, depolarization results in a bidirectional change in MAP2 phosphorylation: a transient increase followed by a long-lasting decrease. Such biphasic regulation of MAP2 phosphorylation may contribute to activitydependent remodeling of postsynaptic structures.

In contrast, the neonatal hippocampus is relatively lacking in pathways that decrease MAP2 phosphorylation in response to glutamate receptor activation (Fig. 9B). In P7 neurons, activation of mGluRs results in an increase in MAP2 phosphorylation. The increase in MAP2 phosphorylation is mediated in part by the activity of MAPKs but, in contrast to the adult, does not involve activation of CaMKs and PKC. The pathway that couples NMDA receptors to MAP2 dephosphorylation is present in $\mathrm{P} 7$ hippocampus; however, it is less influential in the neonate than in the adult. These developmental differences in signaling pathways targeting MAP2 suggest that early in development MAP2 phosphorylation is favored over dephosphorylation. Indeed, depolarization of P7 hippocampal slices resulted exclusively in a net increase in MAP2 phosphorylation. The propensity toward greater MAP2 phosphorylation may promote morphological plasticity by decreasing cytoskeletal stability in the developing brain.

\section{DISCUSSION}

Glutamate receptor activation is fundamental to many forms of activity-dependent synaptic plasticity, including development of the somatosensory cortex in rats (O'Leary et al., 1994), the estab- 

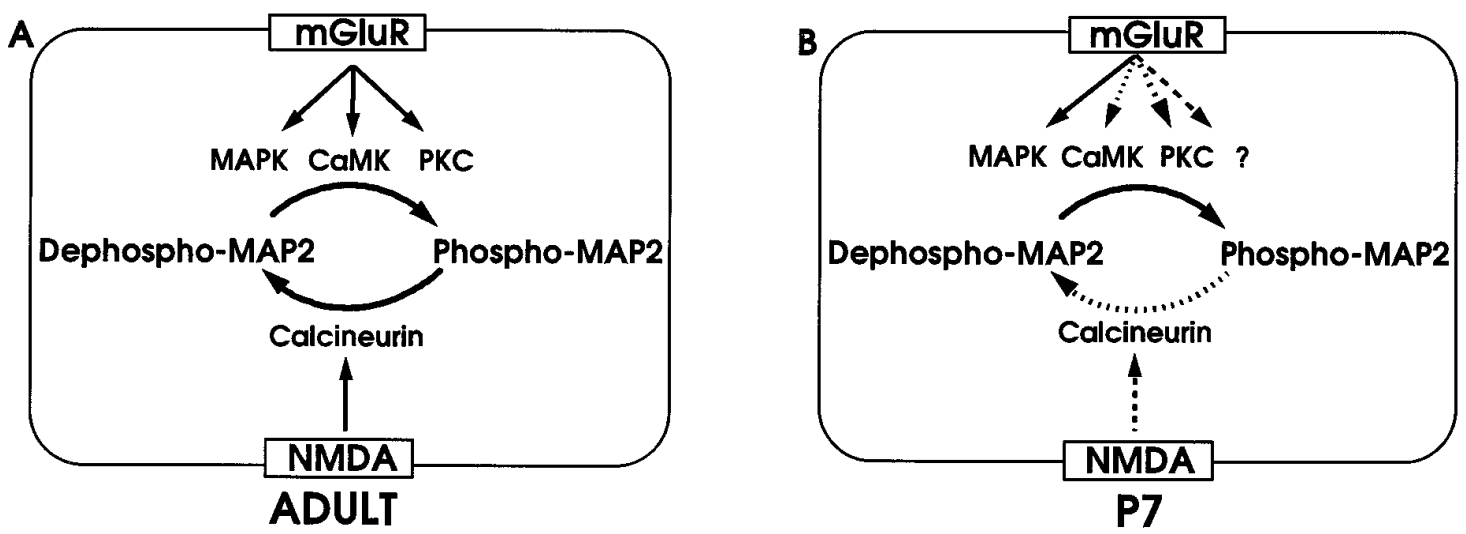

Figure 9. Model for activity-dependent regulation of MAP2 phosphorylation in adult and neonatal hippocampus. MAP2 phosphorylation is regulated by the balance in activity of two antagonistic pathways: increased MAP2 phosphorylation mediated by metabotropic glutamate receptors and activation of MAPKs, CaMKs, and PKC; decreased MAP2 phosphorylation is mediated by NMDA receptors and activation of calcineurin. $A$, In adult hippocampal slices, depolarization of glutamatergic synapses results in the activation of both pathways, resulting in a bidirectional change in MAP2 phosphorylation. $B$, In P7 hippocampal slices, mGluRs are strongly coupled to activation of MAPK, but not to activation of CaMK or PKC. Additional protein kinases may be involved. Although NMDA receptor activation results in a calcineurin-mediated decrease in MAP2 phosphorylation, it is less robust than in the adult. Therefore, depolarization of synapses results in primarily a net increase in MAP2 phosphorylation in P7 hippocampal slices.

lishment of ocular dominance columns in mammals (Daw, 1994), and the formation of retinotectal projections in amphibians (Yen et al., 1993). Glutamatergic signaling has also been shown to induce local changes in the morphology of developing neurons. For example, focal application of glutamate to the growth cones of cultured hippocampal neurons decreases the rate of dendritic outgrowth, although axonal growth rate is unaffected (Mattson et al., 1988). Intuitively, such glutamate-induced changes in neuronal morphology and connectivity involve regulation of the neuronal cytoskeleton. Indeed, many events that characterize the development of neuronal morphology, including elaboration of neurites, process outgrowth, and neuritic branching, involve changes in microtubule organization (Joshi and Baas, 1993; Matus, 1994).

Neuronal morphology is also regulated by a complex network of intracellular signaling pathways. For example, in cultured hippocampal neurons, inhibition of CaMKs decreases the number of dendrites per neuron and the degree of dendritic branching, whereas inhibition of PKC decreases the initiation of neurite outgrowth and the formation of axonal branches (Cabell and Audesirk, 1993). In PC12 and Swiss 3 T3 cells, the protein phosphatase inhibitor okadaic acid induces a rapid and complete breakdown of stable microtubules (Gurland and Gundersen, 1993). Such protein kinase and phosphatase pathways may contribute to various aspects of neuronal structural development by coupling transmembrane signals to changes in cytoskeletal proteins.

High-molecular-weight MAP2 is present in neuronal cell bodies, dendrites, and dendritic spines, but absent from axons and glia, suggesting that MAP2 contributes to the establishment and maintenance of postsynaptic morphology. In vitro, MAP2 promotes tubulin polymerization and actin filament bundling, and the phosphorylation state of MAP2 regulates these interactions with other cytoskeletal elements (Jameson and Caplow, 1981; Nishida et al., 1981; Murthy and Flavin, 1983; Selden and Pollard, 1983). Changes in MAP2 phosphorylation have been observed in the developing cortex and cerebellum (Riederer et al., 1995) and have been correlated with periods of neurite outgrowth in cultured hippocampal neurons (Diez-Guerra and Avila, 1995) and activitydependent synaptic plasticity in the developing visual cortex (Aoki and Siekevitz, 1985). This suggests that the regulation of MAP2 phosphorylation may participate widely in dendrite formation and the activity-dependent sculpting of neuronal postsynaptic specializations.

We have provided evidence that the phosphorylation state of MAP2 is differentially regulated by neural activity in mature and developing neurons. In the adult hippocampus, depolarization stimulates a bidirectional change in MAP2 phosphorylation: a transient increase mediated by mGluRs and activation of MAPKs, CaMKs, and PKC, followed by a long-lasting decrease mediated by NMDA receptors and the activation of calcineurin. In contrast, depolarization of P7 hippocampus results exclusively in a net increase in MAP2 phosphorylation, suggesting that the mechanisms that couple glutamate release to dephosphorylation of MAP2 are relatively lacking in neonatal hippocampus.

In both the adult and the neonate, the increase in MAP2 phosphorylation stimulated by depolarization and mGluR activation is mediated in part by MAPK activity. MAPK is activated by a wide range of extracellular stimuli, including growth factors, mitogens, transmembrane calcium influx, and metabotropic glutamate receptors (Fiore et al., 1993a; Cobb et al., 1994). Accordingly, MAPK has been implicated in many cellular and developmental events, including the regulation of gene expression and the differentiation of neuronal-like PC12 cells (Cowley et al., 1994). Immunoelectron microscopy has demonstrated that MAPK staining in neuronal dendrites is closely associated with microtubules (Fiore et al., 1993b). In addition, MAPK and MAP2 copurify with taxol-stabilized microtubules (Morishima-Kawashima and Kosik, 1996), suggesting that MAPK plays a prominent role in cytoskeletal regulation. Indeed, MAPK was originally identified as a soluble Ser/Thr kinase activity that catalyzed MAP2 phosphorylation in vitro (Ray and Sturgill, 1987). However, to our knowledge this report provides the first direct evidence that MAP2 is an endogenous target of MAPK activity in intact neurons.

MAP2 phosphorylation after glutamate receptor activation has also been examined in cultured hippocampal neurons; however, in these studies only a glutamate-induced increase in MAP2 phosphorylation was reported (Fukunaga et al., 1992). We have observed that incubation of cultured hippocampal neurons with NMDA for 3-10 min induces only a modest decrease in MAP2 phosphorylation (S. Halpain and E. Quinlan, unpublished obser- 
vations), suggesting that the signaling pathways present in relatively immature cultured neurons are similar to those present in the neonatal hippocampus in which NMDA-stimulated MAP2 dephosphorylation is less robust.

Many factors may contribute to the differences in depolarization-induced changes in MAP2 phosphorylation in adult versus neonatal hippocampus. First, glutamate receptor subtypes are differentially expressed over development. For example, the expression of the phospholipase C-coupled metabotropic glutamate receptor mGluR5 (Romano et al., 1996) and glutamate-induced phosphoinositide hydrolysis (Nicoletti et al., 1986) peak during the first week of postnatal development in the hippocampus. In addition, changes in the response properties of NMDA receptors have been observed over development (Westbrook, 1994). Thus, the relative efficacy of mGluR and NMDA receptors may differ in neonates versus adults, which could contribute to the changes in activity-dependent MAP2 regulation that we observe during neuronal maturation.

Second, the levels of intracellular effector molecules are developmentally regulated. For example, levels of the $\mathrm{Ca}^{2+}$-dependent isozymes of PKC are low at birth and increase gradually to adult levels by the fourth postnatal week in rat hippocampus (Jiang et al., 1994). Similarly, the level of CaMKII $\alpha$ mRNA, which is enriched in dendritic postsynaptic specializations, is low at birth and does not reach adult levels until after P25 (Burgin et al., 1990). The developmental expression of MAP kinases remains to be experimentally determined. Although PP1 and PP2A are present at high levels throughout postnatal development (Dudek and Johnson, 1995), calcineurin levels are relatively low at birth and do not reach adult levels until the third postnatal week (Polli et al., 1991). Thus, early in neonatal development, the protein phosphatase pathways that target MAP2 are still relatively immature, perhaps favoring an increase in MAP2 phosphorylation in response to synaptic transmission. Although the protein kinase inhibitors KN62 and CHE effectively inhibited basal MAP2 phosphorylation in the adult and neonate, the observation that depolarization-induced MAP2 phosphorylation is enhanced in P7 hippocampus in the presence of KN62 and CHE remains paradoxical. Negative regulation of CaMKII by PKC in PC12 cells has been observed, in which downregulation of PKC activity by prolonged incubation in phorbol esters augmented the autophosphorylation of CaMKII in response to $\mathrm{K}^{+}$depolarization (MacNicol and Schulman, 1992). It is presently unknown whether the increase in MAP2 phosphorylation that we observe after PKC inhibition is attributable to similar augmentation of CaMK activity. It is possible that certain forms of cross-talk among signal transduction pathways may occur preferentially in immature neurons.

Third, developmental differences in the regulation of MAP2 phosphorylation by $\mathrm{K}^{+}$-induced depolarization may reflect the maturation of the presynaptic apparatus. For example, the presynaptic secretory machinery develops gradually in hippocampal neurons in culture. Before day 6 in vitro, evoked synaptic currents are observed in $<20 \%$ of neurons, but by day 12 this increases to $75 \%$ (Basarsky et al., 1994). Consistent with this time course, synaptosomes prepared from prelabeled hippocampus of P4-P15 rats released significantly less $\left[{ }^{3} \mathrm{H}\right]$ glutamate in response to $\mathrm{K}^{+}$ depolarization than synaptosomes prepared from adult hippocampus (Collard et al., 1993).

Fourth, changes in the expression of high-molecular-weight MAP2 isoforms may account for the developmental differences in MAP2 phosphorylation. Whereas MAP2b is present continuously throughout rat brain development and into adulthood, the highermolecular-weight MAP2a is first detectable at P10 (Riederer and Matus, 1985; Chung et al., 1996). Therefore, the emergence of glutamate-induced bidirectional change in MAP2 phosphorylation may be dependent on the expression of MAP2a. This seems unlikely, because the two isoforms are identical except for an 82-amino-acid insert near the $\mathrm{N}$ terminus of MAP2a. The insert adds five potential Ser/Thr phosphorylation sites; however, a majority of the 40 or more phosphorylatable residues are shared by MAP2a and MAP2b. Indeed, in experiments in which highmolecular-weight MAP2 species could be clearly resolved as a doublet in SDS-PAGE, both isoforms appeared to undergo a similar degree of dephosphorylation in response to NMDA application (E. Quinlan and S. Halpain, unpublished observations).

Finally, it has become increasingly apparent that cellular maturation is accompanied by the establishment of biochemical subdomains that serve to compartmentalize signal transduction events. Enzymesubstrate interactions are regulated, therefore, by anchoring proteins that target protein kinases and phosphatases to specific subcellular regions (see, for example, Coghlan et al., 1995). Developmental changes in molecular distribution may concentrate calcineurin and its substrate MAP2, thereby permitting bidirectional regulation of MAP2 phosphorylation in response to depolarization. An increase in the density of thin-necked or mushroom spines, which could serve to limit the diffusion of effector molecules, has been proposed as a morphological basis of such biochemical compartmentalization in developing synapses (Harris et al., 1992). In the hippocampus, such alterations in spine geometry appear rapidly during the third postnatal week. Interestingly, nondecremental long-term potentiation is also first observed around this time (Harris and Teyler, 1984). Many other physiological, morphological, and biochemical indices suggest that synapses in the developing hippocampus reach a mature state by the third week of postnatal development, including the expression of activity-dependent bidirectional changes in MAP2 phosphorylation.

\section{REFERENCES}

Akiyama T, Nishida E, Ishida J, Saji N, Ogawara H, Hoshi M, Miyata Y, Sakai H (1986) Purified protein kinase C phosphorylates microtubuleassociated protein 2. J Biol Chem 261:15648-15651.

Alessi DR, Cuenda A, Cohen P, Dudley DT, Saltiel A (1995) PD098059 is a specific inhibitor of the activation of mitogen-activated protein kinase kinase both in vitro and in vivo. J Biol Chem 270:27589-27594.

Aoki C, Siekevitz P (1985) Ontogenetic changes in the cyclic adenosine $3^{\prime}, 5^{\prime}$-monophosphate-stimulatable phosphorylation of cat visual cortex proteins, particularly of microtubule-associated protein 2 (MAP2): effects of normal and dark rearing and of the exposure to light. J Neurosci 5:2465-2483.

Basarsky TA, Parpura V, Haydon PG (1994) Hippocampal synaptogenesis in cell culture: developmental time course of synapse formation, calcium influx, and synaptic protein distribution. $\mathbf{J}$ Neurosci 14:6402-6411.

Berling B, Wille H, Roll B, Mandelkow E-M, Garner C, Mandelkow E (1994) Phosphorylation of microtubule-associated proteins MAP2a,b and MAP2c at Ser 136 by proline-directed kinases in vivo and in vitro. Eur J Cell Biol 64:120-130.

Bernhardt R, Matus A (1984) Light and electron microscopic studies of the distribution of microtubule-associated protein 2 in rat brain: a difference between dendritic and axonal cytoskeleton. J Comp Neurol 226:203-221.

Binder LI, Frankfurter A, Kim H, Caceres A, Payne M, Rebhun LI (1984) Heterogeneity of microtubule-associated protein 2 during rat brain development. Proc Natl Acad Sci USA 81:5613-5617.

Burgin KE, Waxham MN, Rickling S, Westgate SA, Mobley WC, Kelly PT (1990) In situ hybridization histochemistry of $\mathrm{Ca}^{2+} /$ calmodulindependent protein kinase in developing rat brain. $\mathrm{J}$ Neurosci 10:1788-1798.

Cabell L, Audesirk G (1993) Effects of selective inhibition of protein kinase $\mathrm{C}$, cyclic AMP-dependent protein kinase, and $\mathrm{Ca}^{2+} /$ calmodulin- 
dependent protein kinase on neurite development in cultured rat hippocampal neurons. Int J Dev Neurosci 11:357-368.

Caceres A, Mautino J, Kosik KS (1992) Suppression of MAP2 in cultured cerebellar macroneurons inhibits minor neurite formation. Neuron 9:607-618.

Charriere-Bertrand C, Garner C, Tardy M, Nunuz J (1991) Expression of various microtubule-associated protein 2 forms in the developing mouse brain and in cultured neurons and astrocytes. J Neurochem 56:385-391.

Chung WJ, Kindler S, Seidenbecher C, Garner CC (1996) MAP2a, an alternatively spliced variant of microtubule associated protein 2 . J Neurochem 66:1273-1281.

Cobb MH, Xu S, Hepler JE, Hutchinson M, Frost J, Robbins DJ (1994) Regulation of the MAP kinase cascade. Cell Mol Biol Res 40:253-156.

Coghlan VM, Perrino BA, Howard M, Langeberg LK, Hicks JB, Gallatin WM, Scott JD (1995) Association of protein kinase A and protein phosphatase 2B with a common anchoring protein. Science 267:108-111.

Collard KJ, Edwards R, Liu Y (1993) Changes in synaptosomal glutamate release during postnatal development in the rat hippocampus and cortex. Dev Brain Res 71:37-43.

Cowley S, Paterson H, Kemp P, Marshall CJ (1994) Activation of MAP kinase kinase is necessary and sufficient for PC12 differentiation and for transformation of NIH 3T3 cells. Cell 77:841-852.

Daw NW (1994) Mechanisms of plasticity in the visual cortex. Invest Ophthalmol Vis Sci 35:4168-4179.

Diez-Guerra FJ, Avila J (1995) An increase in phosphorylation of microtubule-associated protein 2 accompanies dendrite extension during the differentiation of cultured hippocampal neurones. Eur J Biochem 227:68-77.

Dingus J Obar RA, Hyams JS, Goedert M, Vallee RB (1991) Use of a heat-stable microtubule-associated protein class-specific antibody to investigate the mechanism of microtubule binding. J Biol Chem 266:18854-18860.

Doll T, Meichsner M, Riederer BM, Honegger P, Matus A (1993) An isoform of microtubule-associated protein 2 (MAP2) containing four repeats of tubulin-binding motif. J Cell Sci 106:633-649.

Dudek SM, Johnson GVW (1995) Postnatal changes in serine/threonine protein phosphatases and their association with microtubules. Dev Brain Res 90:54-61.

Enan E, Matsumura F (1993) Activation of phosphoinositide/protein kinase $\mathrm{C}$ pathway in rat brain tissue by pyrethroids. Biochem Pharmacol 45:703-710.

Fiore RS, Bayer VE, Pelech SL, Posada J, Cooper JA, Baraban JM (1993a) p42 mitogen-activated protein kinase in brain: prominent localization in neuronal cell bodies and dendrites. Neuroscience 55:463-472.

Fiore RS, Murphy TH, Sanghera JS, Pelech SL, Baraban JM (1993b) Activation of p42 mitogen-activated protein kinases by glutamate receptor stimulation in rat primary cortical cultures. J Neurochem 61:1626-1633.

Fukunaga K, Soderling TR, Miyamoto E (1992) Activation of $\mathrm{Ca}^{2+} /$ calmodulin-dependent protein kinase II and protein kinase $\mathrm{C}$ by glutamate in cultured rat hippocampal neurons. J Biol Chem 267:22527-22533.

Goldenring JR, Vallano ML, DeLorenzo RJ (1985) Phosphorylation of microtubule-associated protein 2 at distinct sites by calmodulin-dependent and cyclic-AMP-dependent kinases. J Neurochem 45:900-905.

Goodman CS, Shatz CJ (1993) Developmental mechanisms that generate precise patterns of neuronal connectivity. Cell 72:77-98.

Goto S, Yamamoto H, Fukunaga K, Iwasa T, Matsukado Y, Miyamoto E (1985) Dephosphorylation of microtubule-associated protein 2, tau factor, and tubulin by calcineurin. J Neurochem 45:276-283.

Gurland G, Gundersen GG (1993) Protein phosphatase inhibitors induce the selective breakdown of stable microtubules in fibroblasts and epithelial cells. Proc Natl Acad Sci USA 90:8827-8831.

Halpain S, Greengard P (1990) Activation of NMDA receptors induces rapid dephosphorylation of the cytoskeletal protein MAP2. Neuron 5:237-246.

Harris KM, Teyler TJ (1984) Developmental onset of long-term potentiation in area CA1 of the rat hippocampus. J Physiol (Lond) 346:27-48.

Harris KM, Jensen FE, Tsao B (1992) Three-dimensional structure of dendritic spines and synapses in rat hippocampus (CA1) at postnatal day 15 and adult ages: implications for the maturation of synaptic physiology and long-term potentiation. J Neurosci 12:2685-2705.
Jameson L, Caplow M (1981) Modification of microtubule steady-state dynamics by phosphorylation of microtubule-associated proteins. Proc Natl Acad Sci USA 78:3413-1417.

Jiang X, Naik MU, Hrabe J, Sacktor TC (1994) Developmental expression of the protein kinase $\mathrm{C}$ family in rat hippocampus. Dev Brain Res 78:291-295.

Joshi HC, Baas PW (1993) A new perspective on microtubules and axon growth. J Cell Biol 121:1191-1196.

Kalcheva N, Albala J, O'Guin K, Rubino H, Garner C, Shafit-Zagardo B (1995) Genomic structure of human microtubule-associated protein 2 (MAP-2) and characterization of additional MAP-2 isoforms. Proc Natl Acad Sci USA 92:10894-10898.

Kindler S, Schulz B, Goedert M, Garner CC (1990) Molecular structure of microtubule-associated protein $2 \mathrm{~b}$ and $2 \mathrm{c}$ from rat brain. J Biol Chem 265:19679-19684.

LeClerc N, Kosik KS, Cowan N, Pienkowski TP, Baas PW (1993) Process formation in Sf9 cells induced by the expression of a microtubuleassociated protein 2C-like construct. Proc Natl Acad Sci USA 90:6223-6227.

Lewis SA, Wang D, Cowan NJ (1988) Microtubule-associated protein MAP2 shares a microtubule binding motif with tau protein. Science 242:936-939.

Ludin B, Matus A (1993) The neuronal cytoskeleton and its role in axonal and dendritic plasticity. Hippocampus 3:61-72.

MacNicol M, Schulman H (1992) Cross-talk between protein kinase C and multifunctional $\mathrm{Ca}^{2+} /$ Calmodulin-dependent protein kinase. J Biol Chem 267:12197-12201.

Mattson MP, Dou P, Kater SB (1988) Outgrowth-regulating actions of glutamate in isolated hippocampal pyramidal neurons. J Neurosci 8:2087-2100.

Matus A (1994) Stiff microtubules and neuronal morphology. Trends Neurosci 17:19-22.

Morishima-Kawashima M, Kosik KS (1996) The pool of MAP kinase associated with microtubules is small but constitutively active. Mol Biol Cell 7:893-905.

Murphy TH, Blatter LA, Bhat RV, Fiore RS, Wier WG, Baraban JM (1994) Differential regulation of calcium/calmodulin-dependent protein kinase II and p42 MAP kinase activity by synaptic transmission. J Neurosci 14:1320-1331.

Murthy ASN, Flavin M (1983) Microtubule assembly using the microtubule-associated protein MAP2 prepared in defined states of phosphorylation with protein kinase and phosphatase. Eur J Biochem 137:37-46.

Nicoletti F, Meek JL, Iadarola MJ, Chuang DM, Roth BL, Costa E (1986) Coupling of inositol phospholipid metabolism with excitatory amino acid recognition sites. J Neurochem 46:40-46.

Nishida E, Kuwaki T, Sakai H (1981) Phosphorylation of microtubuleassociated proteins (MAPs) and $\mathrm{pH}$ of the medium control interactions between MAPs and actin filaments. J Biochem (Tokyo) 90:575-578.

O'Leary DD, Ruff NL, Dyck RH (1994) Development, critical period plasticity, and adult reorganizations of mammalian somatosensory systems. Curr Opin Neurobiol 4:535-544.

Obar RA, Dingus J, Bayley H, Vallee RB (1989) The RII subunit of cAMP-dependent protein kinase binds to a common amino-terminal domain in microtubule-associated proteins $2 \mathrm{~A}, 2 \mathrm{~B}$, and $2 \mathrm{C}$. Neuron 3:639-645.

Polli JW, Billingsley ML, Kincaid RL (1991) Expression of the calmodulin-dependent protein phosphatase, calcineurin, in rat brain: developmental patterns and the role of nigrostriatal innervation. Dev Brain Res 63:105-119.

Quinlan EM, Halpain S (1996) Postsynaptic mechanisms for bidirectional control of MAP2 phosphorylation by glutamate receptors. Neuron 16:357-368.

Ray LB, Sturgill TW (1987) Rapid stimulation by insulin of a serine/ threonine kinase in 3T3-L1 adipocytes that phosphorylates microtubule-associated protein 2 in vitro. Proc Natl Acad Sci USA 84:1502-1506.

Riederer BM (1990) Some aspects of the neuronal cytoskeleton in development. Eur J Morphol 28:347-378.

Riederer BM, Matus A (1985) Differential expression of distinct microtubule-associated proteins during brain development. Proc Natl Acad Sci USA 82:6006-6009.

Riederer BM, Draberova E, Viklicky V, Draber P (1995) Changes of MAP2 phosphorylation during brain development. J Histochem Cytochem 43:1269-1284. 
Romano C, van den Pol AN, O’Malley KL (1996) Enhanced early developmental expression of the metabotropic glutamate receptor mGluR5 in rat brain: protein, mRNA splice variants, and regional distribution. J Comp Neurol 367:403-412.

Rubino HM, Dammerman M, Shafit-Zagardo B, Erlichman J (1989) Localization and characterization of the binding site for the regulatory subunit of type II cAMP-dependent Protein Kinase on MAP2. Neuron 3:631-638.

Sanchez C, Diaz-Nido J, Avila J (1995) Variations in in vivo phosphorylation at the proline-rich domain of the microtubule-associated protein 2 (MAP2) during rat brain development. Biochem J 306:481-487.

Schulman H (1984) Phosphorylation of microtubule-associated proteins by a $\mathrm{Ca}^{2+}$ /calmodulin-dependent protein kinase. J Cell Biol 99:11-19.

Selden CS, Pollard TD (1983) Phosphorylation of microtubuleassociated proteins regulates their interaction with actin filaments. J Biol Chem 258:7064-7071.

Sharma N, Kress Y, Shafit-Zagardo B (1994) Antisense MAP-2 oligonucleotides induce changes in microtuble assembly and neuritic elongation in pre-existing neurites of rat cortical neurons. Cell Motil Cytoskeleton 27:234-247.

Sloboda RD, Rudolph SA, Rosenbaum JL, Greengard P (1975) Cyclic AMP-dependent endogenous phosphorylation of a microtubuleassociated protein. Proc Natl Acad Sci USA 72:177-181.

Tsuyama S, Bramblett GT, Huang KP, Flavin M (1986) Calcium/ phospholipid-dependent kinase recognizes sites in microtubule- associated protein 2 which are phosphorylated in living brain and are not accessible to other kinases. J Biol Chem 261:4110-4116.

Vallee RB (1980) Structure and phosphorylation of microtubuleassociated protein 2 (MAP2). Proc Natl Acad Sci USA 77: $3206-3210$.

Walaas SI, Nairn AC (1989) Multisite phosphorylation of microtubuleassociated protein 2 (MAP-2) in rat brain: peptide mapping distinguishes between cyclic-AMP-, calcium/calmodulin-, and calcium/ phospholipid-regulated phosphorylation mechanisms. J Mol Neurosci 1:117-127.

Westbrook GL (1994) Glutamate receptor update. Curr Opin Neurobiol 4:337-346.

Yamamoto H, Fukunaga K, Goto S, Tanaka E, Miyamoto E (1985) $\mathrm{Ca}^{2+}$, calmodulin-dependent regulation of microtubule formation via phosphorylation of microtubule-associated protein 2, tau factor, and tubulin, and comparison with the cyclic AMP-dependent phosphorylation. J Neurochem 44:759-768.

Yamamoto H, Saitoh Y, Fukunaga K, Nishimura H, Miyamoto E (1988) Dephosphorylation of microtubule proteins by brain phosphatases 1 and $2 \mathrm{~A}$, and its effect on microtubule assembly. J Neurochem 50:1614-1623.

Yen LH, Sibley JT, Constantine-Paton M (1993) Fine-structural alterations and clustering of developing synapses after chronic treatments with low levels of NMDA. J Neurosci 13:4949-4960. 